\title{
SUSTAINABLE DEVELOPMENT MANAGEMENT: REGIONAL ASPECT
}

\section{МЕНЕДЖМЕНТ СТАЛОГО РОЗВИТКУ: РЕГІОНАЛЬНИЙ АСПЕКТ}

\section{Svitlana Lavrynenko ${ }^{1}$ Nataliia Kravchuk ${ }^{2}$}

DOI: https://doi.org/10.30525/978-9934-26-049-0-7

Abstract. In the context of Ukraine's orientation to the European community, taking an active part in global integration processes and strengthening sustainable socio-economic development, the issue of substantiating the essence, identifying features and factors that affect the sustainable development of regions is extremely important. There is a need to develop a new strategy for the development of the national economy, which would help to improve the quality of the ecosystem and provide society with the necessary amount of all resources.

The purpose of the study is to form a set of scientific and methodological provisions for determining the content, concepts, factors and principles of effective management of sustainable development of the regions of Ukraine. The subject of the study are the principles, methods, tools for sustainable development of the regions of Ukraine.

The methodology of the study of sustainable development is to form conceptual approaches to justify the importance of raising the sustainable development of regions.

Sustainable development means any progressive changes, especially in the economic sphere. The essence of sustainable development is substantiated, which consists in a complex-system approach to the consideration of economic, social and ecological values in the process of functioning of economic systems. From the standpoint of taking into

\footnotetext{
${ }^{1}$ Ph.D., Assistant Professor of the Department of Management and Organizations Administering M. Polishchuk,

Polissya National University, Ukraine

${ }^{2}$ Ph.D., Assistant Professor of the Department of Economics and Business,

Polissya National University, Ukraine

(C) Svitlana Lavrynenko, Nataliia Kravchuk
} 
account natural values, economic activity should ensure economic, social and environmental development with minimal destruction of natural and surrounding ecosystems.

It is proved that the management of sustainable development of the region is a complex systemic process that is related to the economic, social and environmental aspects of the region. The implementation of the management mechanism of sustainable development of the region is to ensure the balanced development of all areas of its economy on the basis of balanced management of the use of resources to address economic, social and environmental problems.

\section{1. Ветуп}

Становлення економічної теорії присвяченої питанням сталого розвитку, брало початок з часів створення Римського клубу, коли значна кількість країн з ринковою системою діяльності усвідомили необхідність зміни стратегії піднесення для гармонізації екологічних, економічних та соціальних відносин.

Римський клуб є світовою організацією, що не отримує прибутки об'єднує наукову, економічну, підприємницьку спільноту, а також спеціалістів міжнародних організацій, які переймаються актуальними проблемами суспільства, зокрема економічними, соціальними, екологічними та їх оцінкою і прогнозуванням в контексті світової проблеми сталого розвитку. Дана організаційна структура була заснована у 1968 р. італійським економістом Ауреліо Печчеi, як самостійна структура з метою аналізу та оцінки наслідків нагальних проблем та перспектив розвитку суспільства, активізації діяльності світових організацій та урядів на національному рівні [2, с. 52-64; 3].

На національному рівні управління розвитком регіону в сучасних умовах політико-економічної активності полягає в цілеспрямованій діяльності всіх зацікавлених суб'єктів управління і господарювання під керівництвом органів влади і управління регіону щодо досягнення чітких векторів розвитку на основі ефективної адаптації до постійно змінних факторів зовнішнього середовища. Ефективне управління стійким розвитком регіону залежить від економічної, екологічної та соціальної його складової. 
Одним зі стратегічних завдань розвитку України в сучасній економіці є забезпечення сталого розвитку країни та кожного їі регіону. Термін «сталий розвиток» був закріплений у 1987 р. на Конференції ООН по навколишньому середовищу та розвитку, де дане поняття було визначено як розвиток суспільства, який задовольняє потреби без нанесення шкоди майбутнім поколінням. Найбільш чітке визначення категорії сталого розвитку розглядається в доповіді Гру-Харлем Брутланд в якій відображається, що сталим можна назвати такий розвиток, який веде до мінімізації негативних наслідків виснаження природних ресурсів і забруднення навколишнього природного середовища для майбутніх поколінь у результаті їх соціально-економічного розвитку.

Сталий розвиток передбачає створення такої системи, яка б забезпечувала на довгостроковій основі не тільки високий рівень життя, а й високий рівень іiі якості, не можна назвати систему такою, що розвивається, якщо в ній не примножуються засоби виробництва тощо.

\section{2. Сталий розвиток - поняття категорії}

Поняття “сталий розвиток” - це тонка наукова категорія, яка є підгрунтям чіткого уявлення реалій та вказує на новий період розвитку соціально-економічної системи. Сталий розвиток можна тлумачити як розвиток складної системи “природа - соціум", який забезпечує, як покращання якості життя населення, так і покращання якості екосередовища, що зумовлюють підвищення стійкості цієї системи на довгостроковий періоду.

Перехід на принципи екологічно сталого соціально-економічного розвитку - актуальне стратегічне завдання будь-якої економічної системи, орієнтованої на створення сприятливих соціально-економічних умов життєдіяльності населення. У цьому контексті актуальною постає проблема розробки концептуальних основ екологічно орієнтованого сталого соціально-економічного розвитку. Концепція сталого розвитку передбачає, задоволення визначених потреб сучасного соціуму, що окреслюється двома завданнями, а саме умовами необхідними для існування найбідніших верств населення та обмеженнями, обумовленими можливостями природного середовища задовольняти суспільні потреби. Відповідно, що одним з найпріорі- 
тетніших умов сталого розвитку є екологічний чинник, зміст якого грунтується на необхідності досягнення рівності економічних та екологічних цінностей людства.

Суть сталого розвитку полягає у тому, що економічні, соціальні і екологічні цінності в процесі функціонування економічних систем необхідно розглядати системно. Із позицій врахування природних цінностей, господарська діяльність повинна забезпечувати економічний, соціальний та екологічний розвиток 3 мінімальною руйнацією природних, навколишніх екосистем.

Під стійким розвитком розуміються будь-які прогресивні зміни, перш за все в економічній сфері. Ці зміни можуть бути кількісними, тоді говорять про економічне зростання, або якісним, і тоді говорять про структурні зміни змісту розвитку.

В регіональних масштабах основною метою економічного розвитку є поліпшення якості життя населення. Цілями розвитку регіону $\epsilon$ збільшення доходів, поліпшення освіти, харчування та охорони здоров'я, зменшення бідності, оздоровлення довкілля, рівність можливостей, збагачення культурної життя тощо.

Поряд 3 економічними характеристиками розглядають соціальні параметри розвитку. Більш того, соціальні характеристики є вагомими показниками при оцінці ступеня розвитку регіону.

Обгрунтовуючи, слід зазначити, що реалізація сталого розвитку повинна здійснюватися в регіонах, оскільки вони характеризуються комплексністю, цілісністю, спеціалізацією і керованістю; є історично найбільш стійкими територіальними утвореннями, що сформувалися за період існування; мають найбільш оптимальну структуру для позиціонування на зовнішніх теренах.

\section{3. Фактори сталого розвитку регіону}

Модель сталого розвитку, що передбачає рухливий процес послідовних якісних змін, які забезпечують збалансованість економічного, соціального і екологічного аспектів, повинна лежати в основі формування підходів до вирішення проблем в розрізі територіальних утворень. Це особливо актуально сьогодні, коли відбувається перенесення центру ваги економічних реформ на рівень регіонів і посилення їх ролі в реалізації економічної політики держави. 
Не можна вважати, що регіон стійко розвивається тільки за ознакою підвищення економічних показників. Сталий розвиток має бути націлений на досягнення високої якості життя населення, при позитивній динаміці цілого комплексу показників.

А.О. Підлісна під сталим розвитком регіону розуміє життєздатність системи. При цьому життєздатність системи визначається, як здатність до життя і розвитку, тобто територія, що володіє властивістю стійкості, здатна до виживання та розвитку в конкретному оточенні. Сталість регіонального розвитку визначає здатність регіону зберігати і розвивати значення необхідних параметрів якості життя населення в межах порогу безпеки або вище нього при коливаннях факторів зовнішнього та внутрішнього впливу (суспільно-політичного, соціально-економічного, техногенного, природно-кліматичного й іншого характеру), які загрожують зниженням якості життя населення [7, с. 104-115].

При класифікації регіонів за рівнем і темпами розвитку зазвичай виділяють такі які динамічно розвиваються, проблемні і депресивні регіони. Сталість розвитку економіки регіону як показник якості та зростання досягається в результаті подолання безлічі перешкод i нажаль не завжди є стійким на довготривалий період часу.

Г.І. Карімов до основних форм сталості регіональної системи відносить: несталий розвиток; динамічно сталий розвиток; глобальна сталість; наближений до бажаного сталий розвиток регіональної системи; тривало-стійка система. Регіональні особливості в Україні (за масштабами, регіональним різноманіттям та іншими факторами) вимагають більш ініціативної, активної та швидкої в порівнянні зі звичайною світовою практикою, діяльності держави по усуненню диспропорцій в економічному просторі, вирішення складних регіональних проблем, створення умов для сталого розвитку регіонів [5].

Основні чинники сталого розвитку регіону можна узагальнити у дев'ять груп факторів (рис. 1) [6]:

1) екологічні фактори: запровадження екологічного механізму передбачає збереження екологічної рівноваги, так як, за оцінкою фахівців, природа може «витримати» розвиток промислового виробництва у разі ігнорування екологічних аспектів не більше ніж 20-30 років, а надалі з'являються кризові явища у вигляді втрати лісів, спустошення, погіршення якості прісної води, втрати біологічного різноманіття. 


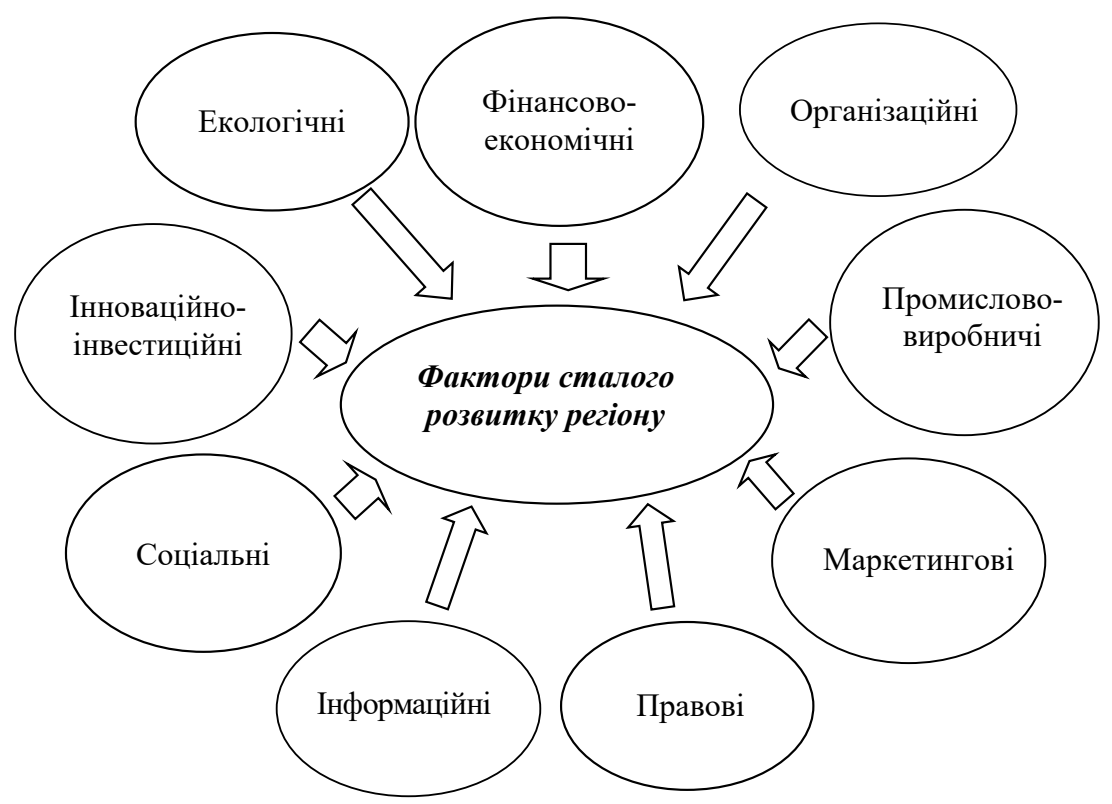

Рис. 1. Фактори сталого розвитку регіону

Джерело: розроблено автором

Дійовими важелями екологічного механізму можуть стати: екологічне страхування як форма відшкодування збитків, заподіяних порушенням права громадян на безпечне для життя та здоров'я довкілля, яке поширене у багатьох країнах $\mathrm{CC}$; екологічна освіта, що охоплює популяризацію екологічної програми національного розвитку; сприяння розробленню й впровадженню екоінновацій; поліпшення інвестиційного клімату в регіоні, за рахунок зниження екологічного ризику; удосконалення екологічної інфраструктури виробничої сфери; стимулювання системи екологічно орієнтованого підприємництва тощо;

2) фінансово-економічні фактори: бюджетна стійкість регіону, часткова самостійність від дотацій, трансфертів 3 державного бюджету; удосконалення фінансово-бюджетних відносин; вироблення критеріїв надання державної підтримки; участь регіонів у державних цільових програмах та проектах, чітка стратегія розвитку регіонів на макро- 
рівні. Важливим аспектом фінансового механізму є вироблення критеріїв та побудова ланцюга надання державної підтримки;

3) організаційні фактори: при забезпеченні сталого розвитку регіону необхідно запровадити такі чинники, щоб територіальні органи були зацікавлені в ефективній роботі всіх підприємств території, незалежно від форми власності, а останні мали відчутну віддачу від комплексного розвитку. Організаційне забезпечення передбачає нову систему управління сталим розвитком, створення цільової організаційної структури - міжвідомчого органу з реалізації стратегії, покликаної забезпечити об'єднання зусиль на різних рівнях управління;

4) промислово-виробничі фактори: наявність потужної промислово-виробничої бази; наявність на територіях регіонів корисних ресурсів;

5) інноваційно-інвестиційнні фактори: потужний розвиток економіки можливий за умов іiі інноваційно-інвестиційної спрямованості, коли, поряд із врахуванням специфічних особливостей країни та національного менталітету, вона стане економічною основою для вирішення економічних, соціальних і екологічних проблем у суспільстві, а також зниження диференціації населення та усунення бідності. Відповідно інноваційний механізм передбачає застосування такої сукупності заходів, які б найефективніше сприяли подоланню проблем і спрямовували розвиток регіону в напрямі інноваційно-інвестиційного, високотехнологічного, ресурсо-ощадного й екологічно безпечного виробництва. Розроблення механізму регулювання розвитку та реалізації інновацій повинне базуватися на системному програмному підході, що дає змогу комплексно підійти до врахування вимог ринку, особливостей розвитку та функціонування певних територій, забезпечити цільову мобілізацію наявних ресурсів, виробити систему дієвих заходів із регулювання та підтримання інноваційного розвитку в регіоні; інноваційний механізм та врегулювання ринкових відносин мають бути спрямовані на раціональне природокористування, зниження навантаження на екосистему;

6) маркетинговий фактор: інформаційна впізнаваємість регіону; наявність державно-відомих брендів регіону тощо;

7) соціальні фактори: повинні сприяти створенню умов для підвищення рівня якості життя населення регіону через запровадження соціальних стандартів, формування оптимальної мережі закладів соціальної інфраструктури, спрямування інвестицій у їх подальший розвиток і під- 
вищення якості послуг. Вектором соціальної оріснтації розвитку регіону необхідно вважати динаміку реального рівня споживання соціальних благ, народжуваність і смертність, фізичне та духовне здоров'я населення, тривалість життя, відповідна соціальна сфера, культура, наукові, освітні заклади та установи; наявність висококваліфікованих кадрів та забезпеченість робочими місцями; діяльність громадських організацій;

8) інформаційний механізм в забезпеченні сталого розвитку регіону полягає у формуванні та застосуванні спеціалізованих комп'ютерних програм для ефективного внутрішнього управління регіоном, у подальшому розвитку інформаційних технологій і систем для надання інформації щодо багатоваріантних аспектів функціонування економіки регіону, у всебічній інформатизації населення, в автоматизації систем господарського управління, глобалізації комп'ютерних мереж через Інтернет та використанні міжнародного досвіду інформаційного регулювання регіонів;

9) дієвість правового механізму: (без якого неможливе контролювання вище згаданих чинників) забезпечення сталого розвитку регіону можливе за умов створення необхідної нормативно-правової бази, що регламентує взаємне представництво інтересів та розмежування повноважень між центральними та місцевими органами виконавчої влади й органами місцевого самоврядування; за наявності системи правових відносин, яка б запобігала дискримінації громадян у різних аспектах суспільного життя та перетворила б Україну на дійсно правову державу. Задля цього необхідно адаптувати національне законодавство з питань регіональної політики до європейських та світових норм і стандартів [1, с. 19-22].

Світовий досвід вказує на використання в практиці при проведенні територіальної оцінки сталого розвитку ряду показників, а саме якісний рівень існування населення (економічна, екологічна та соціальна складові) та безпека життя. Сума показників сталого розвитку відображає індекс сталого розвитку.

На сьогодні, нажаль відсутня єдина загальна світова система показників сталого розвитку. Після проведення конференції ООН в Ріо-деЖанейро було запропоновано систему показників-індикаторів, котрі віддзеркалюють соціальні, економічні та екологічні складові сталого розвитку (132 показника). 
Країни в намаганні реалізації стратегії сталого розвитку встановлюють власний комплексний набір показників. Гострим також $\epsilon$ питання різниці статистичних даних по одним і тим самим показникам. Відсутність потрібних чітко визначених статистичних показників унеможливлює визначення достовірного індексу сталого розвитку.

Україна пропонує підбір власних індикаторів складових економічної безпеки України та стійкого розвитку: соціальна група - рівень життя населення; демографічні показники; якість життя населення, продовольча безпека; економічна група - макроекономічні показники, інвестиційна та інноваційна складова, фінансові та показники зовнішньоекономічної діяльності; екологічна група - забруднення атмосферного повітря, земельні ресурси, ліси, водні ресурси, поводження з відходами, енергетична складова [11, с. 96].

Найвищий індекс сталого розвитку в світі мали (2016 р.)Швеція, Норвегія, Австралія, Фінляндія - 2,90-3,0; найнижчий показник мають Нігерія, Пакистан, Бангладеш, Узбекистан - 1,31. Серед сусідів України найвищий показник має Росія - 2,0 та Казахстан - 1,90. Індекс сталого розвитку України становить - 1,88 [4, с. 11-18].

\section{4. Цілі та принципи управління сталим розвитком регіону}

На сьогодні в Україні ведеться кропітка робота зі встановлення цілей та задач сталого розвитку на 2016-2030 роки, за обгрунтовано визначеними завданнями та показниками 3 метою контролю щодо досягнення цілей. Серед цілей прийнятих на Саміті ООН в рамках 70-ї сесії Генеральної Асамблеї ООН у Нью-Йорку у вересні 2015 року виділено наступні ключові:

- подолання бідності у всіх їі формах та усюди - непропорційний розподіл доходів, занадто низька оплата праці, високий відсоток бідності сімей з дітьми, незбалансований та непропорційний розподіл соціальної допомоги, світова фінансова криза і відповідно ії наслідки, високий рівень пасивності соціуму. Для реалізації даної цілі та i завдань імплементним є формування менеджменту з поєднанням усіх категорій населення, фундаментування принципів рівності статей, підвищення соціальної комунікації, досконале нормативно-правове забезпечення та участь інституційних організацій в управлінні соціальною складовою соціальної політики; 
- досягнення продовольчої безпеки, поліпшення харчування і сприяння сталому розвитку сільського господарства - забезпечення для малозабезпечених та особливо вразливих категорій населення доступ до поживної та безпечної в достатній кількості їжі, в повній мірі задовольняти потреби в харчуванні жіночої статті підліткового віку, вагітних жінок, людей літнього віку, особливо одиноких, досягти створення сталого ланцюга виробництва продуктів харчування та впровадження і реалізація ефективних методів сільськогосподарського виробництва, постійне функціонування продовольчих ринків;

- забезпечення здорового безпечного способу життя та сприяння благополуччю для всіх і у будь-якому віці: знизити смертність материнську, серед дітей віком до 5 років, мінімізувати тютюнокуріння молоді та населення старшого віку та оповіщення про його наслідки;

- забезпечення якісної освіти та заохочення можливості навчання впродовж усього життя для всіх - формування вільного доступу до дошкільної та шкільної освіти дітей, максимізувати доступність професійної освіти та підвищення іiі якості, створити сучасні постійно удосконалюючи умови навчання з використанням інноваційних технологій та інструментів;

- забезпечення гендерної рівності, розширення прав і можливостей жінок - відсутність дискримінації до осіб жіночої статті, мінімізувати домашнє насильство та передчасне запобігання можливим його появам, формування спільної відповідальності за господарювання та дитяче виховання, зниження рівня ранньої народжуваності серед підлітків;

- забезпечення наявності та раціонального використання водних ресурсів - скорочення неочищених викидів води, з застосуванням інновацій при проведенні очищення води, максимізувати ефективність використання води, реалізація удосконаленого управління водоресурсами;

- забезпечення доступу до дешевих, безпечних, сучасних джерел енергії - забезпечення безпечного та постійного електро- та енергопостачання на основі впровадження інноваційних технологій, збільшення відсотку енергії з відновлюваних джерел;

- сприяння сталому економічному зростанню, повній і продуктивній зайнятості та гідній праці для всіх - підвищення внутрішньої валової продукції за рахунок модернізованого виробництва, інноваційного розвитку, збільшення експортного потенціалу, зростання зайнятості насе- 
лення; створення безпечних умов праці для працюючих та надання соціальних гарантій, формування підгрунтя щодо самореалізації наявного потенціалу економічно активної та ініціативної частки населення;

- створення стійкої інфраструктури, сприяння розвитку інновацій розвиток якісної, надійної та доступної інфраструктуру, доступність транспортної інфраструктури, розвиток інноваційної інфраструктуру, що створюватиме платформу до науково-технічного розвитку;

- забезпечення повної відкритості, безпеки, екологічної стійкості міст і населених пунктів - доступність житла для всіх категорій населення, заборона руйнувань існуючих культурних та природних надбань, інформування населення щодо надзвичайного стану, мінімізація негативних шкідливих викидів в атмосферне повітря, побудова стратегій розвитку міст, спрямованих на економічній та інноваційний розвиток;

- забезпечення переходу до раціональних моделей споживання i виробництва - мінімізація ресурсоємності виробничо-економічних процесів, скорочення витрат на виробництво та збут, зменшення обсягів відходів та розширення технологій їх переробки та вторинного використання;

- реалізація невідкладних заходів щодо боротьби з кліматичними коливаннями та їх наслідками - формування спроможності адаптації до небезпечних природно-кліматичних явищ та подій, формування механізмів щодо можливостей планування й управління процесів пов'язаних $з$ кліматичними умовами;

- збереження та раціональне використання водних ресурсів - зменшення забруднення водних ресурсів, збереження морских та берегових екосистем та можливість їх відновлення;

- захист та відновлення екосистем суші та сприяння їх раціональному використанню, раціональне лісокористування - відновлення та постійне використання наземних прісноводних екосистем, лісів, інноваційне відновлення грунтів, захист гірської екологічної системи;

- сприяння побудові відкритого суспільства в інтересах сталого розвитку, створення ефективних, підзвітних інституцій на всіх рівнях - скорочення корупції, ефективне господарювання органів державної та місцевої влади, формування соціальної стійкості та громадської безпеки [14]. 
Процес щодо обгрунтування та визначення державних цілей сталого розвитку з метою досягнення до 2030 р. відбувався в чотирьох напрямах, а саме соціальне піднесення, економічний розвиток та формування зайнятості, ефективний менеджмент, екологічний розвиток та формування стійкості, що забезпечить формування інноваційного піднесення економіки у поєднанні з ефективним використанням природних ресурсів (рис. 2).

Соціальне піднесення. Існуючи соціальні проблеми підсилили плив на показники рівня життя населення через наслідки збройної ситуації що відбувається на східній частині України, через наявність насилля в головній мірі до жінок, зростання бідності, що в цілому негативно впливають на сукупний потенціал країни.

Економічний розвиток та зайнятість. Економічні процеси в Україні та регіонах та їх мінливість не дають змогу нарощення міцного економічного потенціалу, оскільки фінансово-економічна криза вплинула на втрату ресурсів, капіталу та часу, а також конфлікт на Сході України та пандемія COVID-19 значно звужує можливості сталого ефективного зростання. Україна та її регіони гостро потребують інституційних змін та глибоких технологічних рішень. Найактуальнішим $є$ питання щодо зростання ВВП та зайнятості працездатного населення на $65-75 \%$.

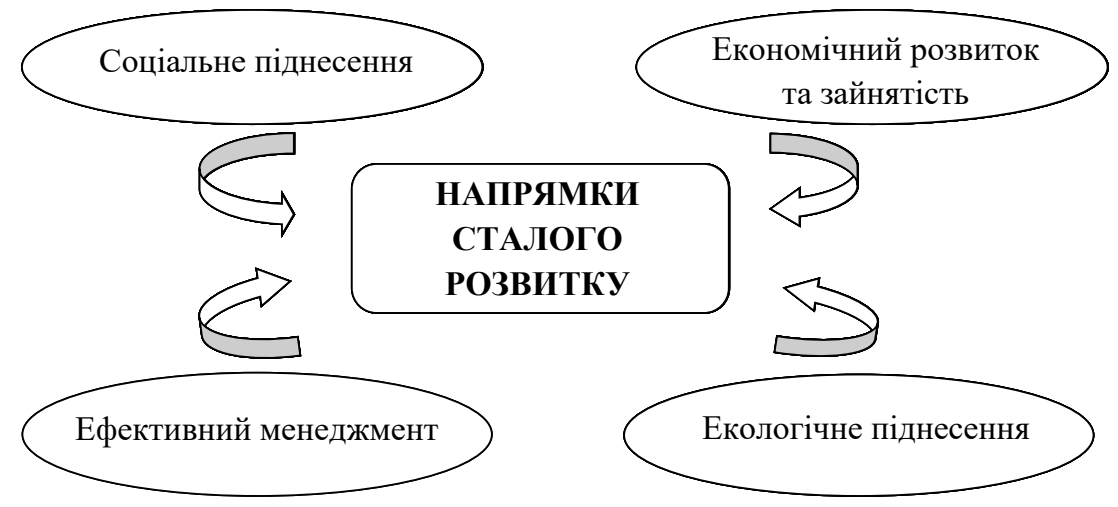

Рис. 2. Напрямки формування цілей сталого розвитку регіону Джерело: розроблено автором 
Ефективний менеджмент. Мета управління у сталому соціально-економічному розвитку регіональної системи має визначатися раціональною організацією, підвищенням ефективності використання всіх видів ресурсів.

Управління регіоном розглядається як динамічна сукупність взаємопов'язаних і взаємозалежних управлінських процесів, а саме: аналізу зовнішнього і внутрішнього середовища регіону, визначення місії регіону, цілей стратегії його розвитку, вибору стратегії функціонування і розвитку регіону, реалізації стратегії розвитку регіону, оцінки реалізації стратегії розвитку регіону, контролю за виконанням.

Не менш важливим в управлінні сталим розвитком $є$ забезпечення безпеки населення, справедливої судової системи, мінімізація корупційних процесів, наявність ефективних дій органів державної та місцевої влади.

Формування системи управління розвитком регіону є складним процесом, здійснення якого вимагає реалізації певних принципів (табл. 1).

\section{Таблиця 1}

\section{Принципи управління стійким розвитком регіону}

\begin{tabular}{|c|c|c|}
\hline 1 & $\begin{array}{l}\text { Принцип } \\
\text { системності } \\
\text { та безперервності }\end{array}$ & $\begin{array}{l}\text { Охоплює всі сфери виробничої і господарської } \\
\text { діяльності на регіональному рівні, визначає цілі } \\
\text { діяльності, їх субординацію, дозволяє порівнювати } \\
\text { альтернативні методи досягнення поставлених } \\
\text { цілей, забезпечує своєчасне розробку та корегування } \\
\text { перспективних планів щодо соціально-економічної } \\
\text { системи регіону та їх узгодженість. }\end{array}$ \\
\hline 2 & $\begin{array}{l}\text { Принцип } \\
\text { взаємозв’'язку } \\
\text { стратегічних планів } \\
\text { розвитку }\end{array}$ & $\begin{array}{l}\text { Здійснюється розробка як по вертикальному (регіон, } \\
\text { економіка в цілому) так і по горизонтальному } \\
\text { ланцюгах (підприємство, постачальники і споживачі } \\
\text { продукції). }\end{array}$ \\
\hline 3 & $\begin{array}{l}\text { Принцип } \\
\text { соціального } \\
\text { партнерства } \\
\text { та взаємодії } \\
\end{array}$ & $\begin{array}{l}\text { Налагодження нового типу відносин між владою, } \\
\text { бізнесом і громадянами, що забезпечує узгодження } \\
\text { їх інтересів і мети, об’єднання ресурсів, розширення } \\
\text { спільної діяльності, обов'язків та відповідальності. }\end{array}$ \\
\hline 4 & $\begin{array}{l}\text { Принцип } \\
\text { адекватності системі }\end{array}$ & $\begin{array}{l}\text { Необхідність проведення оцінки всіх методів } \\
\text { планування та прогнозування, а також розробки } \\
\text { принципово нових моделей системи. }\end{array}$ \\
\hline 5 & $\begin{array}{l}\text { Принцип оцінки } \\
\text { та обліку }\end{array}$ & $\begin{array}{l}\text { Обліковує та надає оцінку особливостям визначеного } \\
\text { регіону та долучення його до світових, федеральних, } \\
\text { міжрегіональних соціально-економічних процесів } 3 \\
\text { метою стратегічного розвитку }\end{array}$ \\
\hline
\end{tabular}

Джерело: адаптовано до джерела [10] 
Екологічний розвиток та формування стійкості. Актуальність питання екологічної стійкості є надзвичайно важливим для України, оскільки виникає необхідності спрямовувати діяльність людини у відповідності з навколишнім природнім середовищем за участю держави 3 метою забезпечення екологічної рівноваги [12, с. 152-160].

На жаль, Україна має досить низький показник у рейтингу екологічної ефективності котрий проводився Йєльським і Колумбійським університетами у співпраці з Всесвітнім економічним форумом, результати якого вказують на місце країн у галузі ефективного управління ресурсами навколишнього природнього середовища (табл. 2) [7].

Однією $з$ найгостріших проблем є робота 3 відходами, масштабність яких зростає, а відсоток тих, що йде на переробку є незначним, а це $\epsilon$ загрозою для довкілля та здоров'я населення. Виснажлива експлуатація земельних, лісових ресурсів, відображається на незворотних втратах екосистеми. Негативним фактором впливу на навколишнє середовище є збройний конфлікт на сході України, наслідком якого $\epsilon$ руйнація природних ландшафтів та інфраструктури [14; 15].

Сталий розвиток - це спроможність окремого сектора та складових організації щодо оптимізації власного внутрішнього накопиченого потенціалу, створення раціональної виробничої структури, яка б при впливі зовнішніх факторів мінімізувала появу негативних наслідків [16, с. 108-114].

Узагальненням $є$ окреслення основних напрямів управління сталим розвитком регіонів, а саме використання синергічного підходу до інтеграції природних та економічних ресурсів, підтримання рівності між економічними, екологічними та соціальними складовими, застосування енерго- та ресурсозберігальних технологій, піднесення та розвиток біоекономіки та органічного виробництва, застосування інтеграційно-системного підходу до управління, зміцнення та поглиблення взаємовідносин між суб’єктами діяльності.

\section{5. Висновки}

Управління сталим розвитком регіону визначається як сукупність проектів, програм, принципів, методів, за допомогою яких планується розвиток соціально-економічної системи на середньострокову або довгострокову перспективу. 
Місце України у світовому рейтингу

Таблиця 2 екологічної ефективності (2019 р.)

\begin{tabular}{|c|c|c|c|c|}
\hline Країни & 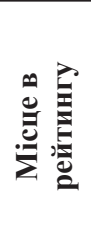 & 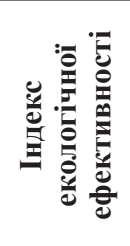 & 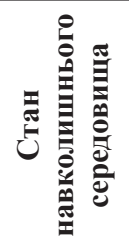 & 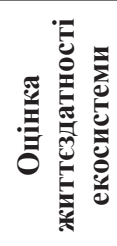 \\
\hline 1. Швейцарія & 1 & 87.42 & 93.57 & 83.32 \\
\hline 2. Франція & 2 & 83.95 & 95.71 & 76.11 \\
\hline 3. Данія & 3 & 81.60 & 98.20 & 70.53 \\
\hline 4. Мальта & 4 & 80.90 & 93.80 & 72.30 \\
\hline 5. Швеція & 5 & 80.51 & 94.41 & 71.24 \\
\hline 6. Об’єднане Королівство & 6 & 79.89 & 96.03 & 69.13 \\
\hline 7. Люксембург & 7 & 79.12 & 95.07 & 68.48 \\
\hline 8. Австрія & 8 & 78.97 & 86.38 & 74.03 \\
\hline 9. Ірландія & 9 & 78.77 & 95.92 & 67.34 \\
\hline 10. Словаччина & 28 & 70.60 & 63.87 & 75.08 \\
\hline 11. Литва & 29 & 69.33 & 72.57 & 67.18 \\
\hline 12. Болгарія & 30 & 67.85 & 69.60 & 66.68 \\
\hline 13. Чеська Республіка & 33 & 67.68 & 68.69 & 67.01 \\
\hline 14. Словенія & 34 & 67.57 & 72.34 & 64.40 \\
\hline 15. Латвія & 37 & 66.12 & 72.80 & 61.66 \\
\hline 16. Угорщина & 43 & 65.01 & 57.67 & 69.90 \\
\hline 17. Білорусь & 44 & 64.98 & 69.55 & 61.94 \\
\hline 18. Румунія & 45 & 64.78 & 58.67 & 68.85 \\
\hline 19. Польща & 50 & 64.11 & 58.71 & 67.72 \\
\hline 20. Росія & 52 & 63.79 & 75.48 & 55.99 \\
\hline 21. Казахстан & 101 & 54.56 & 66.70 & 46.46 \\
\hline 22. Туреччина & 108 & 52.96 & 71.56 & 40.57 \\
\hline 23. Україна & 109 & 52.87 & 64.44 & 45.16 \\
\hline 24. Молдова & 112 & 51.97 & 60.29 & 46.42 \\
\hline 25. Гондурас & 114 & 51.51 & 55.95 & 48.54 \\
\hline
\end{tabular}

Джерело: складено авторами за даними джерела [7] 
При розгляді поняття «сталий розвиток» слід враховувати процесний підхід, відповідно якого сталий розвиток визначається як процес управління, що забезпечує досягнення поставленої мети. Регіональна система виходячи з реалій економічних законів розвивається послідовно, грунтуючись на переході з одного стану в інший. Системність характеризується послідовною зміною фаз, а між двома суміжними циклами знаходиться перехідний період. Під впливом зовнішніх i внутрішніх факторів система може відхилитися від заданої траєкторії руху, що породжує виникнення ситуацій невизначеності.

Таким чином, сталий розвиток регіону - це комплексний процес, що веде до вирішення проблем населення на регіональному рівні, до підвищення умов життя жителів регіону шляхом досягнення збалансованості соціально-економічного та екологічного розвитку, здійснюваного на основі раціонального використання всього ресурсного потенціалу регіону, включаючи географічні особливості регіону, а також особливості економіки, інфраструктури, промисловості і потенційних можливостей окремих міст, що відносяться до даного регіону.

Реалізація управлінського механізму сталого розвитку регіону полягає в забезпеченні збалансованого розвитку всіх сфер його економіки на основі виваженого управління використанням ресурсів для вирішення економічних, соціальних та екологічних проблем. Особливу увагу органам управління при цьому потрібно приділяти вивченню ролі інновацій, складової управління, ефективній роботі всіх підприємств території, а також застосуванню соціальних гарантій та пільг для підвищення якості життя населення.

\section{Список літератури:}

1. Ватченко О.Б. Механізм забезпечення сталого розвитку регіонів України. Науковий вісник НЛТУ Украӥни. 2011. Вип. 21. С. 19-22.

2. Горбатенко В. Римський клуб і організація трансдисциплінарних проектів 3 довгострокового прогнозування глобальних проблем. Політичний менеджмент. 2012. № 3. С. 52-64.

3. Екологія та соціальний захист: програма сталого розвитку України. Римський клуб. URL: http://www.esz.org.ua/?page_id=1195 (дата звернення: 13.02.2021).

4. Захарченко О.В. Оцінка та проблеми сталого розвитку у світі. Вісник ХНАУ ім. В.В. Докучаєва. 2014. № 6. С. 11-18.

5. Карімов Г.І. Регулювання соціально-економічного розвитку регіону з використанням комплексних індикаторів : автореф. дис. ... канд. екон. наук : 08.00.05. Дніпро, 2009. 18 с. 
6. Лібанова Е.М. Соціально-економічний потенціал сталого розвитку України та іiі регіонів: національна доповідь. Київ : ДУ ІЕПСР НАН України, 2014. 776 с.

7. Моніторинг озеленення економіки при реалізації угоди про асоціацію Україна-СС. Київ, 2019. URL: https://www.civic-synergy.org.ua/wp-content/ uploads/2018/04/Monitoryng-ozelenennya-ekonomiky-pry-realizatsiyi-Ugodypro-asotsiatsiyu-Ukrayina-YES.pdf (дата звернення: 12.02.2021).

8. Підлісна О.А. Стан та перспективи розвитку регіонів України: методи оцінки ефективності територіальних утворень. Регіональна економіка. 2007. № 1. C. 104-115.

9. Програма дій «Порядок денний на XXI століття»: Ухвалена конференцією ООН з навколишнього середовища і розвитку в Ріо-де-Жанейро (Саміт «Планета Земля», 1992 р.). Київ : Інтелсфера, 2000. 360 с.

10. Стратегическое управление соціально-экономическим развитием на региональном уровне. Фундаментальные исследования. 2015. Випуск 2 (часть 11). С. 2389-2393.

11. Харазішвілі Ю.М. Прогнозування індикаторів, порогових значень та рівня економічної безпеки України у середньостроковій перспективі. Київ : НІСД, 2014. 117 с.

12. Формування екологічних механізмів стратегічного державного управління розвитком регіонів. Державне управління: удосконалення та розвиток. 2010. № 9. С. 152-160.

13. Цілі сталого розвитку: Україна. URL: http:/un.org.ua/images/SDGs NationalReportUA_Web_1.pdf (дата звернення: 11.02.2021).

14. Цілі сталого розвитку України. URL: http://www.un.org.ua/ua/tsilirozvytku-tysiacholittia/tsili-staloho-rozvytku (дата звернення: 15.02.2021).

15. Чайківський I.A. Механізми забезпечення сталого розвитку сільськогосподарських підприємств. Інноваціийна економіка. 2014. № 6. С. 108-114.

\section{References:}

1. Vatchenko O.B. (2011) Mekhanizm zabezpechennja stalogho rozvytku reghioniv Ukrajiny. Naukovyj visnyk NLTU Ukrajiny, vol. 21, pp. 19-22.

2. Ghorbatenko V. (2012) Rymsjkyj klub i orghanizacija transdyscyplinarnykh proektiv z dovghostrokovogho proghnozuvannja ghlobaljnykh problem. Politychnyj menedzhment, no. 3, pp. 52-64.

3. Ekologhija ta socialjnyj zakhyst: proghrama stalogho rozvytku Ukrajiny. Rymsjkyj klub. URL: http://www.esz.org.ua/?page id=1195 (accessed 13 February 2021).

4. Zakharchenko O.V. (2014). Ocinka ta problemy stalogho rozvytku u sviti. Visnyk KhNAU. im .V.V. Dokuchajeva, no. 6, pp. 11-18.

5. Karimov Gh.I. Reghuljuvannja socialjno-ekonomichnogho rozvytku reghionu z vykorystannjam kompleksnykh indykatoriv [Regulation of socio-economic development of the region with the use of complex indicators]: author ref. dis. ... cand. econ. science. Dnieper. (in Ukrainian)

6. Libanova E.M. (2014) Socialjno-ekonomichnyj potencial stalogho rozvytku Ukrajiny ta jiji reghioniv: nacionaljna dopovidj. Kyiv: DU IEPSR NAN Ukrajiny, 776 p. 
7. Monitoryngh ozelenennja ekonomiky pry realizaciji ughody pro asociaciju Ukrajina-JeS (2019). Kyiv. URL: https://www.civic-synergy.org.ua/wp-content/ uploads/2018/04/Monitoryng-ozelenennya-ekonomiky-pry-realizatsiyi-Ugodypro-asotsiatsiyu-Ukrayina-YES.pdf (accessed 12 February 2021).

8. Pidlisna O.A. (2007) Stan ta perspektyvy rozvytku reghioniv Ukrajiny: metody ocinky efektyvnosti terytorialjnykh utvorenj. Reghionaljna ekonomika, no. 1 , pp. 104-115.

9. Proghrama dij «Porjadok dennyj na XXI stolittja»: Ukhvalena konferencijeju OON z navkolyshnjogho seredovyshha i rozvytku v Rio-de-Zhanejro (Samit «Planeta Zemlja», 1992 r.) (2000). Kyiv: Intelsfera, 360 p.

10. Strateghycheskoe upravlenye socialjno-ekonomycheskym razvytyem na reghyonaljnom urovne (2015). Fundamentaljnble yssledovanyja, vol. 2 (ch. 11), pp. 2389-2393.

11. Kharazishvili Ju.M. (2014) Proghnozuvannja indykatoriv, poroghovykh znachenj ta rivnja ekonomichnoji bezpeky Ukrajiny u serednjostrokovij perspektyvi. Kyiv: NISD, 117 p.

12. Formuvannja ekologhichnykh mekhanizmiv strateghichnogho derzhavnogho upravlinnja rozvytkom reghioniv (2010). Derzhavne upravlinnja: udoskonalennja ta rozvytok, no. 9, pp. 152-160.

13. Cili stalogho rozvytku: Ukrajina. URL: http://un.org.ua/images/SDGs NationalReportUA_Web_1.pdf (accessed 11 February 2021).

14. Cili stalogh̆o rožvytku Ukrajiny. URL: http://www.un.org.ua/ua/tsili-rozvytku-tysiacholittia/tsili-staloho-rozvytku (accessed 15 February 2021).

15. Chajkivsjkyj I.A. (2014) Mekhanizmy zabezpechennja stalogho rozvytku siljsjkoghospodarsjkykh pidpryjemstv. Innovacijna ekonomika, no. 6, pp. 108-114. 